\title{
JobStart
}

\section{Part 1 \\ Getting to Know Yourself}

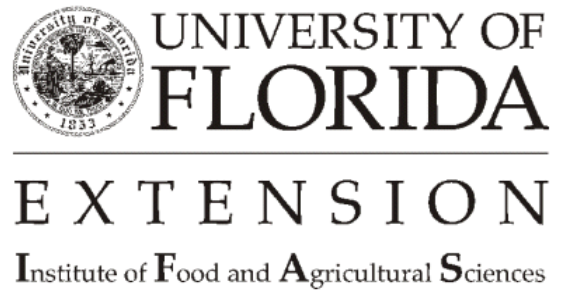




\section{What is A Personal Inventory and Why Is It Necessary?}

Every person that is seeking a job is a salesperson. The product they are trying to sell is themselves, and their customer is the potential employer. A good salesperson will always know their product. For instance: a successful car salesperson will know all the details about the cars for sale on his lot. He will know the engine sizes, the length of the warranty, if it comes with air-conditioning and a stereo, and many other features that may be standard or optional; and he will definitely know the price. If you went to a car salesperson and asked questions about a certain car and you did not get any solid answers, you would probably think that salesperson was hiding something and you wouldn't buy the car. The same is true of potential employers. They have many specific questions and they want to know all the information before hiring a new employee.

- $\quad$ Employers want to know about your job skills.

- $\quad$ They want to know about the successes you have had in previous jobs.

- $\quad$ They want to know about every type of job experience you have ever had.

- $\quad$ They want to know about your education or training experiences.

- $\quad$ They want to know if you respond well to supervision.

- $\quad$ They want to know why you left your last job.

- $\quad$ They want to know why they should hire you.

There are many other questions that a potential employer might ask you. A personal inventory will help you prepare for the kinds of questions a potential employer will ask. It is essential that you be prepared to answer these questions. In order to prepare for getting the job that is just right for you, a personal inventory is required. Many people do not take the time to sit down and think about all the experiences and education they have. Further, they don't consider the skills, talents, and accomplishments that are also important to an employer. A complete and thorough listing of your background and skills is the first step in finding the right job.

A personal inventory is just what the name implies, an inventory or listing that describes you in great detail. Your personal inventory will be like none other since you are a unique and special person. The time you spend on taking a close look at yourself will pay off in every aspect of job hunting and resume preparation. 


\section{How Will A Personal Inventory Help Me?}

The preparation you make in the initial stages of planning your job search will pay off many times. Your personal inventory will help you answer questions in the interview as well as putting the right information on your resume. For example, in the interview you might be asked:

1. What would you say is your one characteristic that would make you a success on the job?

2. What is your most successful accomplishment on a job?

3. What is your main motivation for going to work each day? Is it money or some other satisfaction you get from work?

4. Do you think you would make a good supervisor of other employees, and if so, why?

5. What extracurricular activities did you participate in when you were in school?

These are questions that take time and thought in order to give the best response. Remember, the important thing is not that you are able to answer these questions in an interview, but how you would answer these questions if they are asked. There is no one correct answer to these questions. Each person is unique and responses will vary. The thing to keep in mind is that a well prepared response to a specific question in an interview may be the deciding factor of whether a person is hired for a job.

A personal inventory will help you answer these questions because you will have identified your characteristics, accomplishment, motivation for working, skills and interests. The time you spend in preparing a thorough Personal Inventory will be useful in many ways during the job search and afterward.

Use the individual skills checklist and the transferrable skills checklist to help you prepare the personal inventory.

\section{Individual Skills Checklist}

When it comes to skills that employers look for it is best to divide them into different categories. They are individual skills and transferrable skills. The following list of individual skills are important to employers. Read the list carefully, and decide which of these skills apply to you.

Good attendance

Get along with supervisor

Hardworking, productive

Able to coordinate

Assertive

Humble

Competent
Complete assignments
Creative
Intuitive
Eager
Mature

Competent

Complete assignments

Creative

Eager

Mature
Enthusiastic

Motivated

Formal

Sincere

Patient

Steady 


$\begin{array}{lll}\text { Practice new skills } & \text { Modest } & \text { Industrious } \\ \text { Tenacious } & \text { Flexible } & \text { Informal } \\ \text { Responsible } & \text { Open-minded } & \text { Dependable } \\ \text { Versatile } & \text { Original } & \text { Learn quickly } \\ \text { Honest } & \text { Spontaneous } & \text { Efficient } \\ \text { Get along with co-workers } & \text { Physically strong } & \text { Methodical } \\ \text { Follow instructions } & \text { Take pride in work } & \text { Expressive } \\ \text { Ambitious } & \text { Resourceful } & \text { Natural } \\ \text { Helpful } & \text { Trustworthy } & \text { Optimistic } \\ \text { Cheerful } & \text { Sense of humor } & \text { Solve problems } \\ \text { Independent } & \text { Arrive on time } & \text { Persistent } \\ \text { Conscientious } & \text { Meet deadlines } & \text { Tactful } \\ \text { Intelligent } & \text { Friendly } & \text { Reliable } \\ \text { Discreet } & \text { Good natured } & \text { Thrifty } \\ \text { Loyal } & \text { Capable } & \text { Self-confident } \\ \text { Energetic } & \text { Imaginative } & \text { Well organized }\end{array}$

Adapted by: Elizabeth Bolton, Department of Family, Youth and Community Sciences; Institute of Food and Agricultural Sciences; University of Florida; Gainesville Florida. Adapted from: Shaw, C. \& Wolford N. (1992). The Fact Workbook. Columbus, OH: The Ohio State University.

\section{Transferable Skills Checklist}

The following list of transferable skills are important to employers. A Transferable skill is one that can be used in a variety of jobs, like good communication skills or organizational skills. Read the list carefully, and decide which of these skills apply to you.

$\begin{array}{lll}\text { Meet deadlines } & \text { Written communications } & \text { Research } \\ \text { Plan } & \text { Build things } & \text { Evaluate } \\ \text { Accept responsibility } & \text { Use complex equipment } & \text { Patient } \\ \text { Manage money } & \text { Audit records } & \text { Confront others } \\ \text { Organize projects } & \text { Classify data } & \text { Pleasant } \\ \text { Assemble things } & \text { Synthesize } & \text { Demonstrate } \\ \text { Repair things } & \text { Administer to people } & \text { Insightful } \\ \text { Investigate } & \text { Persuade } & \text { Tough } \\ \text { Calculate or compute } & \text { Control budgets } & \text { Articulate } \\ \text { Detail oriented } & \text { Increase sales or efficiency } & \text { Motivate people } \\ \text { Take inventory } & \text { Solve problems } & \text { Delegate } \\ \text { Care for people } & \text { Negotiate } & \text { Self motivated } \\ \text { Speak in public } & \text { Use my hands } & \text { Music appreciation } \\ \text { Supervise others } & \text { Operate tools or machinery } & \text { Counsel people } \\ \text { Instruct others } & \text { Analyze data } & \text { Sociable } \\ \text { Meet the public } & \text { Keep financial records } & \text { Teach }\end{array}$




$\begin{array}{lll}\text { Listen } & \text { Expressive } & \text { Logical } \\ \text { Inventive } & \text { Sensitive } & \text { Decisive } \\ \text { Competitive } & \text { Diplomatic } & \text { Self controlled } \\ \text { Direct others } & \text { Tolerant } & \text { Artistic } \\ \text { Take risks } & \text { Outgoing } & \text { Perform or act }\end{array}$

Adapted by: Elizabeth Bolton, Department of Family, Youth and Community Sciences; Institute of Food and Agricultural Sciences; University of Florida; Gainesville Florida. Adapted from: Shaw, C. \& Wolford N. (1992). The Fact Workbook. Columbus, OH: The Ohio State University.

\section{How to Make a Weakness a Strength}

Everyone has what might be called weaknesses and strengths in terms of capabilities for a certain job. For example, you might not know how to operate a word processor, or know the latest software programs, or have the required number of years of experience the job notice calls for. These are weaknesses. On the other hand, you might have just the right kind of experience called for in the job notice, the appropriate experience and all the required capabilities for the job. These are strengths. The task is to take a weakness and turn it into a strength for the purpose of presenting yourself in the most favorable way for a job application or interview.

Often employers will ask a job candidate to identify a weakness that they have and how that might affect their performance on the job. It is best to be prepared for this type of question with a well prepared response, because no one is perfect, and if you tell the potential employer that you are perfect, you might come across as either hiding something or being arrogant.

One way to handle this type of question is to turn that weakness into a strength. For example: Let's say that your weakness is that you get irritated with other co-workers easily when they make mistakes on the job. This could be bad for the morale of workers around you, especially if you are verbal with your dissatisfaction of their performance. Most employers would rather the supervisors handle poor performance among workers instead of a fellow worker criticizing them.

One thing you could say about this weakness is that you get irritated so easily because you hold yourself to such a high standard that you expect others around you to do the same; and when they do not it irritates you. You should also say that you have realized this weakness in the past and have made conscious efforts to improve yourself by helping other co-workers with their mistakes instead of criticizing them. This way you come across to the potential employer as someone with high standards who is willing to work as a team member to help other workers who might have problems.

Another example of a weakness might be consistent lateness to work, appointments, or inability to stay on a schedule. This shows up in the workplace as not being able to get to work on time. In fact, you got fired from your last job because of consistent lateness. Turn this negative experience into a 
positive by listing the steps you have (or are willing) take to break this bad habit. You might want to read about time management, take a course at the local community college on time management, or set personal goals for yourself and say how you met (or plan to meet) them. The important thing is to know which of your work habits need correcting and how you plan to do so. Better still, how you have eliminated the weaknesses.

The thing to remember is that any weakness you tell the potential employer is one that you have been aware of for a while and that you have made efforts to improve yourself in this area. The first step is to identify those areas you think a potential employer would see as a weaknesses. What is the one weakness that gives you the most trouble? What weakness do you have that would keep you from being successful at work? Think carefully about your weaknesses and how you would turn them into strengths. List your strengths and weaknesses and then write out a plan on how you propose to make a weakness into a strength.

\section{What Are Your Strengths and Weaknesses?}

Corwen (1995) identified attributes that contribute to success on the job. These are listed and defined below. Assess the strength of these attributes for yourself. If you feel that you have a weakness in some of these attributes, plan a strategy for strengthening them.

\section{Do you feel that you are:}

1. Ambitious? Are you career oriented with a strong desire to attain personal and financial success?

2. Articulate? Are you able to communicate ideas and opinions clearly and forcefully?

3. Cheerful? Are you pleasant; able to smile easily?

4. Confident? Do you have a high level of self-esteem? Are you self-assured?

5. Conscientious? Do you have good work habits? Are you able to take on unpleasant tasks? Are you punctual?

6. Cooperative? Are you helpful; a good team worker?

7. Dependable? Are you steady? Do you keep promises? Do you have good work habits?

8. Efficient? Do you make good use of time; perform high quality work?

9. Energetic? Do you have a high level of mental and physical endurance; work quickly? 
10. Industrious? Are you hard-working; eager to take on difficult tasks?

11. Loyal? Are you supportive of the best interests of your employer and colleagues?

12. Organized? Are you orderly; an efficient planner?

13. Self-Controlled? Are you slow to anger? Do you keep your head in tense situations?

Adapted from Corwen, Howard. 1995. Your Resume: Key To A Better Job. McMillan Publishing: New York. pp. 157-158.

Knowing about yourself will help you choose the right job. Attitudes, values, likes and dislikes are among the personal inventory items that need close attention in preparing to look for a job.

\section{How Do You Feel About Work?}

The following statements will help you determine how you feel about work. You may have some additional feelings that are not listed here. You may want to discuss these feelings with someone whose opinion you value.

- $\quad$ Going to work makes me nervous.

- $\quad$ I like working more than playing.

- $\quad$ Looking for a job scares me stiff.

- $\quad$ I'm fired up to look for a job.

- $\quad$ I'm only looking for work because I have to.

- $\quad$ My job is the most important thing in my life.

- I always wish it were Friday.

- I don't want to keep any one job more than a year or two.

- Work really fulfills me.

- I wish I had more education so I could get a better job.

- I want to work more than I want to earn money.

- $\quad$ I want to earn money more than I want to work. 
- $\quad$ I will take any job I can get.

- I can't wait to start work

\section{Why Do You Want To Work?}

There are many personal needs for people who want to work. These needs vary from person to person dependent upon personalities, desires, and lifestyles. Some of these needs are listed here, but there may be others that fit your situation. Which of these needs are really important to you?

\section{Economic Needs}

- $\quad$ I want to save for long term goals (home, car, trips, and education).

- I want to keep my family together during a crisis (illness, divorce, unemployment).

- $\quad$ I want to save money.

- I want fringe benefits (medical and life insurance).

\section{Social Needs}

- I want to meet people and make friends.

- I want to be with people who share my interests.

- I want to raise my social status.

- I want to help others.

\section{Personal Needs}

- I want to feel a sense of achievement.

- I want to increase my self-confidence and self-esteem.

- $\quad$ I want to feel secure.

- I want to be a part of a purpose or a group of people.

- I want to use my skills, knowledge, and education.

- I want to be recognized and valued by others. 


\section{What are Your Job Needs?}

Just as personal needs vary for individuals who want to work, there are also job needs. It is important for you to know how to place priorities on these job needs because they have a direct bearing on the type of job you will want to focus on. Which needs from the list below are the most important to you?

- $\quad$ Length of vacation.

- $\quad$ Amount of sick leave.

- $\quad$ Number of hours worked per day.

- $\quad$ Amount of money earned.

- $\quad$ Amount of status in the job.

- Advancement.

- $\quad$ How you feel doing the job.

- Location.

- $\quad$ People you work with.

- $\quad$ Working indoors or outdoors.

- $\quad$ Amount of medical insurance.

- When you work: days, nights, swing shift.

- $\quad$ Amount of responsibility.

- $\quad$ Retirement age.

- $\quad$ Long term security of job.

- $\quad$ Amount of travel.

Adapted by: Elizabeth Bolton, Department of Family, Youth and Community Sciences; Institute of Food and Agricultural Sciences; University of Florida; Gainesville Florida. Adapted from: Shaw, C. \& Wolford N. (1992). The Fact Workbook. Columbus, OH: The Ohio State University. 


\section{Why Are Values Important in the Workplace?}

What is a value? How do values affect who we are and what we do?

All of us are influenced daily by our values. We are aware of some values, but others have been learned at such an early age that we do not recognize we are behaving in accord with them. In working with others, it is important to be aware of their values as well as our own. It is the first step toward making a decision that will reflect well on oneself and also be right for the other person.

Generally speaking a value is something that is measured in importance, worth, or desirability. It is the primary influence on the many decisions we make throughout the day. We are all influenced daily by our values. They guide the way we act and feel about certain things, situations, and people. Acceptance of the values of others is important in human relationships. It increases understanding and makes working together easier.

Values are abstract concepts of worth or what we think is good. They guide the way we act and feel about certain things, situations, and people. Tolerance for the value systems of others is an important attitude in human relationships. It increases understanding and makes working relationships easier.

A value is not in itself either good or bad. Values can and do change. This is easy to see when we consider how the standards for male and female behavior have changed over time. When we travel to other areas, we can see that other people look at the world differently, interpret what they see in other ways, and have feelings about situations that are different from ours.

Values also affect job satisfaction. If the job you have does not meet your values you may leave and seek work elsewhere. What is it that you value most in a job? Pay, work hours, location, working with people, prestige, solving problems?

Would the values of a nurse be different from a stock broker?

Would the values of a construction worker be different from a nursery school attendant?

Our values affect every decision that we make. That is why it is so important to understand our values when choosing a job or career. It could have a great impact on how happy we are in that job.

\section{Can I Use Values at Work?}

What values do people want in co-workers or supervisors?

Seth Godin (1995) conducted a survey of business virtues dealing with habits, attitudes and skills that employers look for in an employee. According to Godin, the top ten virtues turned out to be: 
- $\quad$ Ethics

- $\quad$ Teamwork

- Honesty

- Curiosity

- $\quad$ Hard work
- Intelligence

- $\quad$ Self-motivation

- $\quad$ Sense of Humor

- $\quad$ Initiative

- Creativity

Godin notes that these virtues are not easy habits. Rather they are skills that have to be learned. How do you feel about these business virtues. Do they reflect any of your values? How might these virtues/values make you more successful in the workplace?

\section{Work Values}

Listed below is are some work values that affect job satisfaction. Which of these are important to you?

- Challenge: I want to solve problems on the job.

- $\quad$ Competence: I want a job that I am able to do well.

- $\quad$ Creativity: I want to use my own ideas.

- Enjoyment: I want a job that is fun.

- Environment: I want clean, healthy working conditions.

- $\quad$ Fame: I want people to know about me and my work.

- Independence: I want to work without close supervision.

- Job Security: I want a steady job I can count on.
- Knowledge: I want a job where I can learn new things.

- Money: I want to earn more money.

- $\quad$ People: I want to work with people.

- Personal Satisfaction: I want to feel worthwhile.

- $\quad$ Physical Mobility: I want to move around; not sit.

- $\quad$ Power: I want to make decisions and be the boss.

- Relationships: I want to know and like people at work.

- $\quad$ Respect: I want people to look up to me. 
- $\quad$ Service to Others: I want to help others.

- $\quad$ Social: I want to visit with people at work.

- $\quad$ Solitude: I want to be by myself at work.
- $\quad$ Time: I want a job with no overtime.

- Understood Tasks: I want to be told what to do.

- Variety: I want to do many different activities.

\section{Preparing Your Personal Inventory}

When you prepare your personal inventory, consider all your experiences relevant to work, your skills, your reason for working, how you feel about work, your job needs, and your values. The failure to prepare a personal inventory will mean that you are not fully prepared for developing your resume or for a personal interview. Getting to know yourself will help build your confidence for the interview. The hardest questions you will have to answer are those about yourself. Your personal inventory should include all the information that is listed here.

\section{Education}

- $\quad$ School name, address, phone

- Years Attended

- $\quad$ Major Studies

- GPA/Class Rank

- Honors

- In which school or college courses did you excel?

- In which courses did you do poorly?

- Which subjects did you enjoy most?

- $\quad$ Are you willing to continue your studies in order to increase your knowledge of the field you have chosen?

- $\quad$ Any schooling you have had aside from your formal education.

- Any extracurricular activities you have participated in with a description of your accomplishments.

\section{Employment}

- $\quad$ Employer name, address, phone

- Dates of employment

- Hours per week

- Salary/pay

- $\quad$ Supervisor's name and title

- Duties 
- $\quad$ Skills utilized

- Accomplishments/awards

- Other important information

- $\quad$ If you have you ever been fired from a job; if it was your fault (give an explanation)

- $\quad$ Duties in which you excelled

- $\quad$ Any part-time jobs you had while in school or after graduation with a description of your duties

\section{Volunteer Activities}

- $\quad$ Organization name, address, phone

- Dates of employment

- Hours per week

- $\quad$ Supervisor's name and title

- Duties

- $\quad$ Skills utilized

- $\quad$ Accomplishments/awards

- Other important information

\section{Activities, Aptitudes}

- Club/activity

- $\quad$ Offices held

- Description of participation

- Duties/responsibilities

- Job specific skills (typing, computer operation, painting, cooking, masonry, etc.)

- Hobbies or personal interests

- $\quad$ Organizations you have been or are now associated with

\section{Achievements}

- $\quad$ Your main achievements ( in school, job, personal)

- $\quad$ Promotion and salary record for each job you have held

- $\quad$ Community outreach activities, such as fund-raising, organizing, or social work

\section{Military Service}
- Branch
- $\quad$ Rank (at discharge)
- Dates of service
- Duties and responsibilities 
- $\quad$ Special training and/or school attended

- Citations, awards

- $\quad$ Specific accomplishments

\section{Language}

- $\quad$ Language - which one(s); whether you

- Read

- Write

- Converse

- $\quad$ Background (number of years studied, travel, etc.)

\section{Miscellaneous}

- $\quad$ The kind of work would you prefer to do ( all of your preferences, no matter how unrelated to your education or experience)

- Whether or not salary is your primary consideration

- Willingness to sacrifice income to do the kind of work you most enjoy (explanation)

\section{References}

Beatty, R. H. (1986). The Five Minute Interview. New York: John Wiley and Sons, Inc.

Corwen, H. (1995). Your Resume: Key To a Better Job, pp. 157-158. New York: MacMillan Publishing.

Farr, J. (1994). The Quick Resume and Cover Letter Book. Indianapolis, IN: JIST Works Inc.

Fry, R. (1993). Your First Interview (Second Edition). Hawthorne, N.J.: The Career Press.

Godin, S. (1995). Wisdom, Inc., pp. 4-7. New York: Harper Collins Publishers, Inc.

O’Brien, J. (1996). The Complete Job Search Organizer: How To Get a Great Job--Fast. Washington, DC: The Kiplinger Washington Editors, Inc.

Shaw, C. \& Wolford, N. (1992). The Fact Workbook. Columbus, OH: The Ohio State University. 
This document is FY345, Part 1 of an 8 part series developed for the Department of Family, Youth and Community Sciences, Cooperative Extension Service, Institute of Food and Agricultural Sciences, University of Florida.

Revised version prepared for electronic publication November 2001 by Elizabeth B. Bolton, professor, community development, Department of Family, Youth and Community Sciences, Extension Cooperative Service, Institute of Food and Agricultural Sciences, University of Florida, Gainesville, 32611-0310.

Original version prepared for publication May 1997 by Elizabeth B. Bolton, professor, community development, Department of Family, Youth and Community Sciences and George O. Hack, assistant in Department of Family, Youth and Community Sciences, Extension Cooperative Service, Institute of Food and Agricultural Sciences, University of Florida, Gainesville, 32611-0310.

The Institute of Food and Agricultural Sciences is an equal opportunity/affirmative action employer authorized to provide research, educational information and other services only to individuals and institutions that function without regard to race, color, sex, age, handicap, or national origin. For information on obtaining other extension publications, contact your county Cooperative Extension Service office.

Florida Cooperative Extension Service/Institute of Food and Agricultural Sciences/University of Florida/Christine Taylor Waddill, Dean 